\title{
Strategies for Avoiding Business: Failure of Local Franchise
}

\author{
Yessy Artanti \\ Department of Management \\ Universitas Negeri Surabaya \\ Surabaya, Indonesia \\ yessyartanti@unesa.ac.id
}

\author{
Nindria Untarini \\ Department of Management \\ Universitas Negeri Surabaya \\ Surabaya, Indonesia \\ nindriauntarini@unsa.ac.id
}

\author{
Sanaji \\ Department of Management \\ Universitas Negeri Surabaya \\ Surabaya, Indonesia \\ sanaji@unesa.ac.id
}

\begin{abstract}
This study aims to implement the entrepreneurial marketing and adversity intelligence on business performance of local franchise. The criteria of selecting respondents are domestic franchiser companies (local) in the field of food and beverages service which are included in the AFI (Association of Franchise Indonesia) in small and medium scale with sampling based on the response rate. Sampling technique used was purposive sampling and data anaylis was done by using Partial Least Square (PLS). The results show that the implementation of entrepreneurial marketing and adversity intelligence positively influence and can increase the business performance of local franchise in Surabaya. This electronic document is a "live" template and already defines the components of your paper [title, text, heads, etc.] in its style sheet.
\end{abstract}

Keywords- Local franchise, balance scorecard, business performance, entrepreneurial marketing, adversity intelligence

\section{INTRODUCTION}

The interesting phenomenon of recent years is the growing fruits of food and beverage franchise business. The business form of a franchise can be described as a combination of big and small businesses, a blend of individual energy and commitment to the resources and strengths of a large company [1]. In general, franchise is a relatively safe alternative for prospective entrepreneurs who want to plunge into own business or companies that want to plunge into own business or for a company that wants to change its branch or agency system into a leaner and tougher marketing machine. Franchise is based on a harmonious, open, and continuous relationship between franchisors and franchisees. A less harmonious relationship because of different vision, mission, and shared values between the franchisor on the one hand and the franchisee on the other hand will lead to business failure, business performance degradation, and eventually the business will disperse.
Research on the consequences of franchising for franchisees especially local franchise has been rare. A few important efforts have contrasted survival rates for franchisees with independent business. Although the concept of franchise proved to be very effective, but the development of Indonesian local franchise is still left behind compared to foreign franchise. Some local franchises are popping up, but some of them have also gone bankrupt. This is due to the unpreparedness of infrastructure owned by local franchisors as the "Foster Father", which should help developing its franchisees [2]. In addition to the above problems, there are still more complex issues, including: First, many franchisees do not comply with the provisions outlined in standard operating procedures (SOPs) such as non-standard taste/quality among outlets. Second, the franchise fee scheme that creates a conflict due to incriminating fees, the difference in net profit calculation, and the franchisee's discontent in the future day of the royalty amount charged at the start of the agreement. Third, there is a feeling of discrimination from the fanchisee. Realized it or not, these problems lead to great problems potential. Discrimination may occur in the form of fee negotiations, sales targets, site selection, physical facilities, assistance, and categorization. For example, outlets belonging to franchisees located in strategic areas are often subject to higher sales targets from non-strategic areas. Fourth, the franchisor ignores the promise of such assistance and obligations. Fifth, the franchisee outlet does not achieve the expected profit and feel disappointed and cheated to undertake undue action on the frachise brand. In franchising field, a local entrepreneurfranchise purchase form a firm (the franchisor) the right to use its brand name and operating system. Franchising is an important for entrepreneurship and also to the economy.

\section{LITERATURE REVIEW}

Failure of this local franchise business has become an interesting topic to be researched and at the same time tried to find a solution. Research conducted by [3] states that one of the 
causes of franchise business failure or the cause of many local franchises lossy is the weak or low quality relationship between franchisor and franchisee which causes business performance degradation. In addition [4] who reviewed the food franchise business in Indonesia suggested that the failure factors of local franchise and often ignored by Indonesian franchisee are managerial incompetence and having no experience. Although the franchisor provides training and management assistance, there must be a high level of commitment from the franchisee and all his staff. They have to work hard and carefully, and must always strictly maintain the quality of products and services. Once they neglect this because of a weak control system then the customer will switch to a competitor. Food business has a high sensitivity to quality and price. A very important factor of the success of the food franchise business in Indonesia is the power of consumer demand. This is supported by their purchasing power.

Marketing is a fundamental problem which is also faced by small entrepreneurs including in this case is a franchise business. The concept of entrepreneurial marketing is basically a discipline that studies about the value, ability and behavior of an entrepreneur in dealing with various related problems in an effort to get business opportunities. The entrepreneurial marketing approach is an appropriate conceptual approach in terms of resource constraints and problems that exist in small businesses [5]. The entrepreneurial marketing approach to small entrepreneurs is able to create a more directed business condition related to the effort of achieving the predetermined objectives. An important aspect of marketing in the context of entrepreneurship is to see how marketing theory fits into entrepreneurial practice. This is in accordance with the opinion of [6] which states that the concept of marketing run by entrepreneurs show the difference from the concept stated in conventional marketing. Conventional marketing is considered to be an organized and planned process. The concept of conventional marketing assumes that consumer needs are identified through formal market research. The results of the market analysis will be used as the basis for the development of new products or services in response to consumer needs. Entrepreneurial or entrepreneurial marketing behavior on the other hand can be said to be a behavior that represents a more informal and unplanned activity that relies on the intuition and energy of individuals to realize business activities [7]. This statement explains that managers - owners of small and medium enterprises need to combine conventional marketing with entrepreneurship. Managers-owners of small and medium enterprises have been assuming the concept of marketing as something that big companies do [5].

Bjerke [8] suggests marketing entrepreneuship in small enterprises are targeting organizations or individuals that have a positive or negative effect on products, prices, promotions and distribution channels versus interactive marketing and word of mouth. Marketing strategy is implemented through marketing activities that are better known as marketing mix, which is a tool used by marketers. Bjerke [8] stated that entrepreneuship marketing activity is a process of direct exchange and the establishment of personal relationships. Entrepreneurs prefer interactive marketing. Managers-Owners of small enterprises are those who have the ability to interact with the market target because they have a strong preference in personal contact with consumers and not through impersonal marketing through mass promotions. Relationship through conversation is taken as a way of listening and responding to the voice of the consumers instead of doing formal market research to understand the market.

Generally, the ability of managers-owners to engage in dialogue with customers is often a unique selling point for businesses. The owner manager typically spends some of his working day in contact with consumers and interacts with the consumer base in a way that big companies do, even those with the latest technology [9] Interactive marketing for small enterprises contains the ability to communicate and respond quickly to individual consumers. Entrepreneurs interact with individual consumers through personal selling and relationshipbuilding approaches, which will not only ensure ordering, but also provide recommendations to consumers. The OwnerManager emphasizes the importance of personal relationships in building a consumer base.

Interaction with existing consumers is done by using wordof-mouth marketing to spread the message. Entrepreneurial marketing relies on word-of-mouth communication to create a customer base through their recommendations. [10], states that the entrepreneurial marketing process describes the four marketing principles and behaviors of entrepreneurial activity as a result of comparison between the marketing theory in standard textbooks such as [6] and marketing that has been successfully conducted by entrepreneurs and managers of entrepreneurial business. According to [6], comparisons of traditional marketing principles and entrepreneurial marketing can be seen in table 1 .

TABLE I. TRADITIONAL MARKETING PRINCIPLES AND ENTREPRENEURIAL MARKETING

\begin{tabular}{|l|l|l|}
\hline $\begin{array}{c}\text { Marketing } \\
\text { Principle }\end{array}$ & \multicolumn{1}{|c|}{$\begin{array}{c}\text { Traditional } \\
\text { Marketing }\end{array}$} & \multicolumn{1}{c|}{$\begin{array}{c}\text { Entrepreneurial } \\
\text { Marketing }\end{array}$} \\
\hline Concept & $\begin{array}{l}\text { Oriented on consumers, } \\
\text { market support, and } \\
\text { product development. }\end{array}$ & $\begin{array}{l}\text { Oriented on innovation, } \\
\text { ideas support, and } \\
\text { intuitive estimation of } \\
\text { market needs. }\end{array}$ \\
\hline Strategy & $\begin{array}{l}\text { Topdown, targeting, } \\
\text { and positioning } \\
\text { segmentation. }\end{array}$ & $\begin{array}{l}\text { Bottom-up target from } \\
\text { consumers and other } \\
\text { influence groups. }\end{array}$ \\
\hline Metode & $\begin{array}{l}\text { Marketing } \\
\text { combination, Four P / } \\
\text { Seven P. }\end{array}$ & $\begin{array}{l}\text { Interactive marketing } \\
\text { method, word of mouth } \\
\text { marketing. }\end{array}$ \\
\hline $\begin{array}{l}\text { Market } \\
\text { Intelligence }\end{array}$ & $\begin{array}{l}\text { Formal research and } \\
\text { intelligence system. }\end{array}$ & $\begin{array}{l}\text { Informal network and } \\
\text { information gathering. }\end{array}$ \\
\hline
\end{tabular}

Source: Stokes, 2007.

Table 1 explains that the concept of entrepreneurial marketing is focused on innovation and idea development in accordance with the understanding of market needs; traditional marketing assumes that an estimate of consumer needs leads to the development of a product or service. Entrepreneurs target consumers through a bottom-up approach to the market, not through the segmentation, targeting and top-down positioning of traditional marketing. Entrepreneurial marketing prefers interactive marketing methods, which use the word of mouth news to find new consumers. Entrepreneurial marketing is 
described by the collection of informal information through a network of personal contact, not collection of systematic market intelligence which is in the text of traditional marketing.

Table 1 shows that marketing is not something new to entrepreneurs, but it is not always based on conventional marketing theory. Entrepreneurial marketing is able to increase the entrepreneurial power with emphasis that the entrepreneurial aspect can be incorporated in the marketing principle. [6] explains on the basis of his research that good marketers generally come from individuals with high entrepreneurial spirit. The entrepreneurial spirit makes one easy to form a powerful marketer, who is highly sensitive to environmental developments and quickly capture them as an open market opportunity to create products to be offered in the market.

In addition to entrepreneurial marketing, this research seeks to implement how the level of adversity intelligence of business actors and its impact on business performance. According to [11] adversity intelligence is an ability to change the barriers into an opportunity to achieve success goals. Meanwhile, according to [12] adversity intelligence is the ability to think, manage and direct the actions that form a pattern of cognitive and behavioral responses to the stimulus events in life that is a challenge or difficulty. According to [11], intelligence in facing individual barriers has four dimensions, namely CO2RE: Control, Origin Ownership, Reach, and Endurance. Control (C) means how much control we can feel for an event that causes difficulties. The most important aspect of this dimension is the extent to which individuals can perceive that control plays a role in adverse events such as being able to control certain situations and so on. Origin dan Ownership (O2) means who or what causes difficulties and the extent to which a person considers himself to influence himself as the cause and origin of difficulties such as regrets, experiences, and so on. Reach $(\mathrm{R})$ is part of the IA that asks the question of the extent to which the difficulties encountered will reach other parts of the individual's life such as panic barriers, obstacles due to laziness and so on. Thus Endurance (E) can be interpreted as resilience that is a dimension that questions two things related to how long the cause of the difficulties will continue and the individual's response to time in solving problems such as time is not a problem, the ability to complete the job quickly and so fort.

Based on the above description, it can be concluded that to know the intelligence in facing obstacles is not only to know what is needed to improve it, but what is also needed to be paid attention is the dimensions in order to understand the intelligence in facing obstacles comprehensively. Individuals in dealing with difficulties within themselves are driven by some of the responses that direct these individuals in decisionmaking. There are several responses that encourage individuals in facing various difficulties in themselves.

\section{RESEARCH METHOD}

\section{A. Sampel}

In addition to franchise companies listed in Association of Franchise Indonesia, there are still many franchise companies that have not been registered in the Franchise Association of Indonesia (AFI). The population of this study is the franchise company in Surabaya city whether it has been registered in AFI or not which is in the field of food and beverage business. The sampling technique used was non-probability sampling with purposive sampling with criteria of local franchise companies in the field of food and beverages service in AFI and added with local franchise companies which do not participate in AFI, both small and medium enterprises.

\section{B. Independent Variables}

- Entrepreneurial marketing is a marketing aspect that focuses on the need to create and develop a network which is capable for supporting company. The entrepreneurial marketing variable in this study is operated multi-dimensionally and multi-indicator. There are four indicators used to measure entrepreneurial marketing variables according to [6]: concepts, strategies, methods, and market intelligence.

- Adversity intelligence is an ability to turn obstacles into an opportunity to achieve success goals through the ability to think, manage and direct the actions that shape a pattern of cognitive and behavioral responses to the stimuli of events in life that are challenges or difficulties. The dimensions used are: Control, Origin Ownership, Reach, and Endurance.

\section{Dependent Variable}

- Business performance uses Balance Scorecard measurement that divides performance into financial performance, marketing performance, process and operation performance, and learning and growth performance.

\section{Data Analysis}

Analytical technique of this research is structural equation model (SEM) with Partial Least Square (PLS) approach and using SmartPlus software.

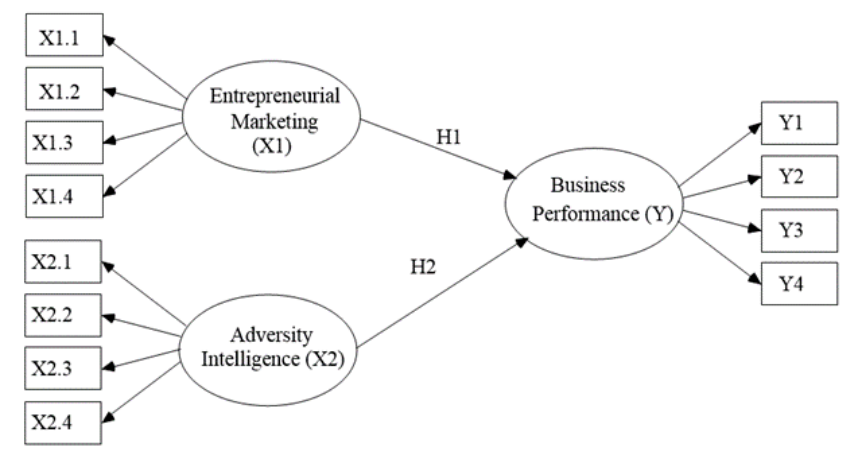

Fig. 1. SEM Diagram 

$\mathrm{X} 1.1$ : Concept
$\mathrm{X} 1.2$ : Strategy
X1.3: Method
X1.4 : Market Intelligent

Y1 : Financial Performance

Y2 : Marketing Performance

Y3 : Process Performance

Y4 : Learning and growth performance

\section{RESULTS}

The results of questionnaires distributed to 56 small and medium scale franchisees operating in the food and beverage business show that the duration of the sample business ranges from 3 to 9 years, in which most of them have been operating for 3 years (43\%) and only one company has operated for 9 years $(2 \%)$. In terms of type of business, most operate in food business $(84 \%)$, while the rest operate in beverage business $(16 \%)$

Result of validity test with item-total correlation shows that there are 2 items fall for adversity intelligence variable and 5 items for business performance variable. Thus, of the 32 items used, the remaining 25 items were analyzed further. To test the research hypothesis, the researchers used Partial Least Square (PLS) method. PLS is a structural equation model (SEM) that is component or variance based. PLS is selected, because the sample size of this study is only 56 observations, less than 5 times the number of menifest variables, if using covariance-based SEM. The model analysis procedure using PLS includes three stages. First, assessing the outer model or measurement model is an assessment of the reliability and validity of research variables. There are three criteria to assess the outer model: convergent validity, discriminant validity and composite reliability. Second is assessing the inner model or structural model. Inner model or structural model testing is done to see the causal relationship between constructs to be tested, significance value and Rsquare of the research model. Third is model validation to find out whether the model is worth using.

\section{A. Outer Model (Measurement Model) Testing}

The template is designed so that author affiliations are not repeated each time for multiple authors of the same affiliation. Please keep your affiliations as succinct as possible (for example, do not differentiate among departments of the same organization). This template was designed for two affiliations.

\section{1) Convergent Validity Testing}

Convergent validity is used to test whether the indicators used can accurately measure latent constructs [13]. In this study the latent variable indicator is represented by a dimension score that has previously been tested for its validity and reliability. Convergent validity test on PLS can be seen from the amount of loading factor of each indicator to its latent variable. This loading factor is identical to the simple correlation between the indicator score and the latent variable score or its factor. The cut-off value required to conclude that an indicator precisely measures the latent variable at least 0.5 or a significant t-statistic value $(>1.96)$. If it does not meet these criteria then the indicator will be removed from the model. The results of the convergent validity test of the research indicators are presented in table 2 .

\section{TABLE II. RESULTS OF CONVERGENT VALIDITY TEST}

\begin{tabular}{|c|c|c|c|c|c|}
\hline \multirow{2}{*}{ Construct } & \multirow{2}{*}{ Indicator } & \multicolumn{2}{|c|}{ Original Model } & \multicolumn{2}{|c|}{$\begin{array}{c}\text { Upgrading } \\
\text { Model }\end{array}$} \\
\hline & & $\begin{array}{c}\text { Factor } \\
\text { loading }\end{array}$ & $\begin{array}{c}T- \\
\text { Statistic } \\
\end{array}$ & $\begin{array}{l}\text { Factor } \\
\text { loading }\end{array}$ & $\begin{array}{c}T- \\
\text { Statistic } \\
\end{array}$ \\
\hline \multirow{4}{*}{$\begin{array}{l}\text { Entrepre- } \\
\text { neurial } \\
\text { Marketing } \\
\text { (X1) }\end{array}$} & $\begin{array}{l}\text { Concept } \\
(\mathrm{X} 1.1)\end{array}$ & 0.537 & 3.061 & 0.534 & 3.290 \\
\hline & $\begin{array}{l}\text { Strategy } \\
(\mathrm{X} 1.2)\end{array}$ & 0.757 & 2.862 & 0.753 & 3.148 \\
\hline & Method (X1.3) & 0.746 & 2.574 & 0.753 & 3.655 \\
\hline & $\begin{array}{l}\text { Market } \\
\text { Intelligence } \\
(\mathrm{X} 1.4)\end{array}$ & 0.237 & 0.676 & & \\
\hline \multirow{4}{*}{$\begin{array}{l}\text { Adversity } \\
\text { intelligence } \\
\text { (X2) }\end{array}$} & Control (X2.1) & 0.961 & 11.398 & 0.963 & 35.549 \\
\hline & $\begin{array}{l}\text { Origin and } \\
\text { Ownership } \\
(\mathrm{X} 2.2)\end{array}$ & 0.879 & 5.429 & 0.861 & 10.837 \\
\hline & Reach (X2.3) & 0.320 & 1.250 & & \\
\hline & $\begin{array}{l}\text { Endurance } \\
(\mathrm{X} 2.4)\end{array}$ & 0.554 & 3.076 & 0.586 & 3.970 \\
\hline \multirow{4}{*}{$\begin{array}{c}\text { Business } \\
\text { Performance } \\
\text { (Y) }\end{array}$} & Financial (Y1) & 0.726 & 8.200 & 0.720 & 8.668 \\
\hline & $\begin{array}{l}\text { Marketing } \\
(\mathrm{Y} 2)\end{array}$ & 0.856 & 8.012 & 0.860 & 14.612 \\
\hline & $\begin{array}{l}\text { Business } \\
\text { Process (Y3) }\end{array}$ & 0.691 & 4.195 & 0.691 & 4.611 \\
\hline & $\begin{array}{l}\text { Learning and } \\
\text { Growth (Y4) }\end{array}$ & 0.845 & 18.719 & 0.844 & 20.146 \\
\hline
\end{tabular}

The result of the convergent validity test in table 2 shows that not all indicators meet the criteria, because the loading factor is $<0.50$, so it is excluded from the model for the next analysis. There are two indicators that do not meet the criteria, namely market intelligence (X1.4) for entrepreneurial marketing variable and reach (X2.3) indicator for adversity intelligent variable. Therefore, for further analysis both indicators were excluded from the model, and re-analyzed.

\section{2) Discriminant Validity Test}

Good measurement is unidemensinal, that is, it can precisely measure what is measured (convergent) and does not measure another construct (discriminant). Discriminant validity is used to test whether the indicators of a construct are not highly correlated with other construct indicators or at least they are correlated lower with other construct indicators (14). Discriminant validity test can be done by: (1) Comparing loading and cross loading, (2) average variance extracted (AVE), and (3) contrasting with the correlation among latent variables. Discriminant validity test results with the three criteria are presented in table 3 and table 4 . Cross loading is a simple correlation between indicators with other latent variables that exist in the model. Ideally, the loading factor should be greater than cross loading, so it can be considered that the indicator does not measure the different constructs of the constructs that should be measured. 
TABLE III. CROSS LOADINGS FOR DISCRIMINANT VALIDITY TEST

\begin{tabular}{|c|c|c|c|c|c|}
\hline \multirow[b]{2}{*}{ Construct } & \multirow[b]{2}{*}{ AVE } & \multirow{2}{*}{$\begin{array}{l}\text { Error! } \\
\text { Objects } \\
\text { cannot be } \\
\text { created } \\
\text { from } \\
\text { editing } \\
\text { field } \\
\text { codes. }\end{array}$} & \multicolumn{3}{|c|}{ Correlation Matrix } \\
\hline & & & 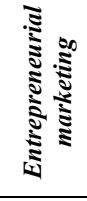 & 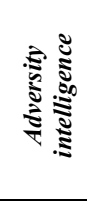 & 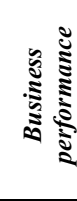 \\
\hline $\begin{array}{l}\text { Entrepreneurial } \\
\text { marketing }\end{array}$ & 0.473 & 0.688 & 1.000 & & \\
\hline $\begin{array}{l}\text { Adversity } \\
\text { intelligence }\end{array}$ & 0.670 & 0.819 & 0.441 & 1.000 & \\
\hline $\begin{array}{l}\text { Business } \\
\text { performance }\end{array}$ & 0.612 & 0.782 & 0.599 & 0.421 & 1.000 \\
\hline
\end{tabular}

Based on table 3, it is known that one business performance indicator, that is business process performance, its factor loading value is lower than cross loading, while for indicators of entrepreneurial marketing and adversity intelligence have met the criteria. This shows that based on the data, business process indicator correlates higher with entrepreneurial marketing variable than with its own constructs. The indicators are maintained, because discriminant validity testing in addition to use cross-loading, it can also be done by comparing with the correlation among latent variables. AVE denotes the ability of the latent variable values in representing the original data score (before extracted). AVE is identical to multiple R2 (coefficient of determination), so the greater the AVE, the greater the representation of the original variable values by factor scores. Cut-off value of AVE is $\geq 0.50$. The value of Average Variance Extracted (AVE) and correlation among latent variables are presented in table 4.

TABLE IV. AVERAGE VARIANCE EXTRACTED (AVE) AND CORRELATION AMONG LATENT VARIABLES

\begin{tabular}{|c|c|c|c|c|}
\hline Construct & Indicator & $\begin{array}{c}\text { Entrepre } \\
\text {-neurial } \\
\text { Marke- } \\
\text { ting }\end{array}$ & $\begin{array}{c}\text { Adversity } \\
\text { Inteligence }\end{array}$ & $\begin{array}{c}\text { Business } \\
\text { Perform } \\
\text { ance }\end{array}$ \\
\hline \multirow{3}{*}{$\begin{array}{l}\text { Entrepreneu- } \\
\text { rial } \\
\text { Marketing } \\
\text { (X1) }\end{array}$} & Concept (X1.1) & 0,534 & 0,244 & 0,302 \\
\hline & Strategy (X1.2) & 0,753 & 0,230 & 0,256 \\
\hline & Method (X1.3) & 0,753 & 0,117 & 0,458 \\
\hline \multirow{3}{*}{$\begin{array}{l}\text { Adversity } \\
\text { Intelligence } \\
\text { (X2) }\end{array}$} & Control (X2.1) & 0,519 & 0,963 & 0,477 \\
\hline & $\begin{array}{l}\text { Origin and } \\
\text { Ownership } \\
(\mathrm{X} 2.2)\end{array}$ & 0,477 & 0,861 & 0,350 \\
\hline & $\begin{array}{l}\text { Endurance } \\
\text { (X2.4) }\end{array}$ & 0,179 & 0,586 & 0,186 \\
\hline \multirow{4}{*}{$\begin{array}{l}\text { Business } \\
\text { Peeformance } \\
\text { (Y) }\end{array}$} & Financial (Y1) & 0,306 & 0,478 & 0,720 \\
\hline & Marketing (Y2) & 0,813 & 0,564 & 0,860 \\
\hline & $\begin{array}{l}\text { Business Process } \\
\text { (Y3) }\end{array}$ & 0,959 & 0,142 & 0,691 \\
\hline & $\begin{array}{l}\text { Learning and } \\
\text { Growth (Y4) }\end{array}$ & 0,774 & 0,313 & 0,844 \\
\hline
\end{tabular}

Based on table 4 , the value of AVE of entrepreneurial marketing variable $=0.473<0.50$. This is due to the relatively low indicator loading value, although $>0.50$ (table 4.2), and this becomes a limitation of the study in the context of its construct measurement. Furthermore, the discriminant validity test criterion by comparing with the correlation among latent variables shows that the value of each latent variable is greater than its correlation with other latent variables. These results indicate that the indicators or dimensions used to measure the construct have good discriminant validity.

\section{3) Composite Reliability Testing}

Reliability reflects the consistence of measurements made repeatedly on the same subject. If the result is consistent, then the measuring instrument is considered reliable. Reliability testing is done by using composite reliability, in which the results are presented in table 5 .

TABLE V. COMPOSITE RELIABILITY

\begin{tabular}{|l|c|}
\hline \multicolumn{1}{|c|}{ Construct } & Composite Reliability \\
\hline Entrepreneurial Marketing & 0.725 \\
\hline Adversity intelligence & 0.855 \\
\hline Business Performance & 0.862 \\
\hline
\end{tabular}

General guidelines used to infer reliable measuring instruments; there is composite reliability test if it has a value of $\geq 0.70$. Based on table 5 , the level of reliability of the measurement variable is good, because each latent variable has a composite value reliabllity $>0.70$.

\section{B. Inner Model (Structrural Model) Testing}

The next step in PLS analysis is to test the inner model or structural model. As SEM analysis in general, inner model testing includes two stages: (1) testing the goodness of fit and (2) testing the significance of the path. Testing of path coefficients in inner model also means to test the hypothesis proposed in this study because the formulated hypothesis is reflected in the paths that exist in the model. Results of inner models processed with SmartPLS presented in figure 2.

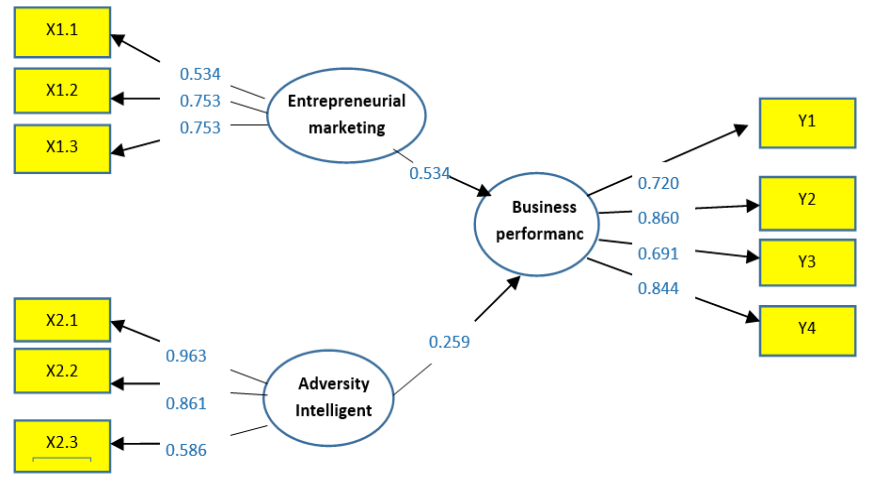

Fig. 2. Inner Model improvement (Original Sample Estimate)

1) Goodness of fit Testing

This testing is meant to recognize how far model result able to explain data (score) variance of original variable. Testing is 
done using Stone-Geisser Q Square test. From inner model, it is known that there is a dependent variable that is, business performance, therefore it is obtained one coefficients of determination. From the output of PLS, it is obtained that value of coefficient of determinations is 0,444 , therefore it can be interpreted that the ability of entrepreneurial marketing and adversity intelligent in explaining business performance of franchise companies is $44,4 \%$

\section{2) Hyphotesis Testing}

There are 2 hyphothesis proposed in this study. Hypothesis testing in PLS analysis basically is proposed to test significance of path coefficient in the model. To conclude whether path or reearch hypothesis are proven, it uses Cut-off value value of tcount $=1,96[14]$. Therefore, if tcount in the tested path $\geq$ 1,96 , so the research hypothesis is proven. The result of the path coefficient testing is presented in table 6 .

TABLE VI. HyPOTHESIS TESTING RESULTS

\begin{tabular}{|c|c|c|c|c|c|c|}
\hline 苗 & Path & 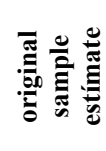 & 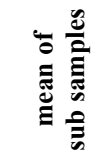 & & 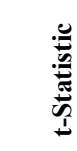 & 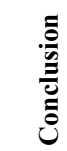 \\
\hline $\mathrm{H} 1$ & $\begin{array}{l}\text { Entrepreneurial } \\
\text { Marketing -> } \\
\text { Business } \\
\text { Performance }\end{array}$ & 0,534 & 0,531 & 0,092 & 5,825 & $\begin{array}{l}\mathrm{H} 0 \\
\text { rejec } \\
\text {-ted }\end{array}$ \\
\hline $\mathrm{H} 2$ & $\begin{array}{l}\text { Adversity } \\
\text { intelligent } \\
\text { Business } \\
\text { Performance }\end{array}$ & 0,259 & 0,292 & 0,129 & 2,013 & $\begin{array}{l}\mathrm{H} 0 \\
\text { rejec } \\
\text {-ted }\end{array}$ \\
\hline
\end{tabular}

The result of the path coefficient testing in table 6 shows that entrepreneurial marketing has a positive effect on the business performance of franchise business in Surabaya and adversity intelligent proved to positively affect the performance of franchise business in Surabaya. Noticing the path coefficient value, entrepreneurial marketing has a greater impact, equivalent to twice the adversity intelligent influence on business performance of a franchise companies. These result indicates the importance of entrepreneurial marketing to achieve the success of small and medium business enterprises such as franchise.

\section{DISCUSSION}

This study supports the findings of some experts. [15] states that there is a direct link between entrepreneurship marketing and sales results. [15] emphasizes business performance as measured financially in the form of sales proceeds. In line with this research, one of the dimensions of business performance is financial performance. Similar with the results of research [16] which concludes that entrepreneurship marketing influences business performance from the growth rate of sales and profits. Through entrepreneurial marketing, the business owner can conduct a thorough evaluation as an effort in determining the right policies in an effort to improve business performance including sales and profits [17]. The results of this study are supported by the theory put forward by [18] saying that the entrepreneurial business portrayed in its capacity to plan ahead, its capacity to innovate and risk-taking will make it easier to innovate, as well as develop and grow successfully. [19] who stated that entrepreneurship tends to be oriented to innovation based on new ideas and market conditions that are not consumer oriented, or that are controlled by the expectation of market wants and needs. Entrepreneurs target their markets through bottom-up and consumer recommendations and other top-down group influences targeting and positioning the process.

The results of this study support the hypothesis that adversity intelligent has a significant positive effect on business performance. Similar to entrepreneurial marketing variables, in variable of adversity intelligen, not all dimensions contribute to the business performance. The third dimension, reach, must be removed from the model because it does not meet the criteria, i.e. its loading factor $<0,50$. The statements representing this dimension are: (1) I have the ability to see the cause of the problem, and (2) I have the ability to see new opportunities. This statement received less response from respondents because most respondents in this study have an average business length of three years. Actually aspect of the ability to see new opportunities already exists in selfrespondents but because the business is run a franchise where SOP (Standart Operational Procedure) and criteria others have been determined by the franchisor then this dimension is considered less relevant in the franchise setting.

\section{MANAGERIAL IMPLICATIONS}

In this scope of study, franchise business, even though the majority of business activities is specified by the franchisor, but the ability to change difficulties to be opportunity is absolutely required by the franchisee. An individual having intelligent of confronting obstacles is thought to be more likely easier undergoing a profession as an entrepreneur because it has the ability to turn barriers into opportunities [11]. The franchisee is individuals who have the courage and intelligence to capture and start a new business because they already have the initial capital that is the ability to bear the risk, orientation on opportunities / initiative, creativity, independence and resource mobilization. But due to limitations in terms of experience opening up the market and introducing a new brand, the franchise format is usually chosen for new start-up business

\section{CONCLUSIONS}

Based on the aforementioned results, it is concluded that the performance of local franchise business can be improved by applying the entrepreneurial marketing and adversity intelligent. The implication of this research is that the proliferation of local franchise business, actually, is not accompanied by the sustainability of the business. Many local franchisees mainly occur at the level of the franchisee closing down the business or not continuing the business again. If the reason to close the franchise business is because it wants to open a business of course it is very good, but if the reason is because of the lack of business management, then it is very unfortunate. Therefore, based on the results of this study the franchisee must also have the ability to apply entrepreneurial marketing that not only focuses on product innovation but 
rather on the ability to see what the market wants both in terms of goods and services. The ability to see opportunities is not only absolutely done by the franchisor but through a two-way interaction between the franchisor and the franchisee. It is expected they work together to generate new bids. After doing research, the researcher realized that there are still some limitations in this research, that is: (1) At the time of distributing the questionnaire, some respondents at the site were the employees and not business owners. This causes difficulties in answering statements. It is recommended in further research that email and social media are also used for larger scope instead of direct distribution as this study had been done and (2) the questionnaire used to measure business performance in this study is Balance Scorecard. This measuring tool would be more meaningful if the company measured is a large company and has long established. This measuring tool would be more meaningful if the company measured is a large company and has long established. As it is known that the object of this study is a small and medium scale business and most of them is newly established 3 years (result of questioner distribution)

\section{REFERENCES}

[1] Y. Ambadar, Jackie, Miranty, dan Isa, Membeli dan Menjual Franchise. Jakarta: Yayasan Bina Karya Mandiri, 2006

[2] S. Muharam, Sukses Membeli. 2003.

[3] M. Hapsari, "Pengaruh Kualitas Manajemen, Motivasi Kewirausaahaan, Dan Pengelolaan Merek Terhadap Kualitas Hubungan Franchise Dalam Meningkatkan Kinerja Penjualan," 2008.

[4] Astuti, "Kajian Bisnis Franchise Makanan di Indonesia," J. Manaj. dan Kewirausahaan, vol. 7, pp. 83-98, 2005.
[5] D. Stokes, "Putting Entrepreneurship Into Marketing," J. Res. Mark. Entrep., vol. 2, 2007.

[6] Kotler, "Manajemen Pemasaran," 11th ed., PT. Indeks Kelompok Media, 2008.

[7] G. Day, John., Reynald, Pane, and Lancaster, "Entrepreneurship and The Small to Medium Sized Entrepries.," Manag. Decis., vol. 44, pp. 581-587, 2006.

[8] Bjerke and Hultman, “"Entrepreneurial Marketing: the Growth of Small Firms in the New Economic Era,"' Int. Small Bus. Journa, pp. 110 113, 2006.

[9] E. Gummesson, "Qualitative research in management: addressing complexity, context and persona," Manag. Decis., vol. 44(2), pp. 167179.

[10] C. \& M. M. Hills, Gerald \& Hultman, "The Evolution and Development of Entrepreneurial Marketing," J. Small Bus. Manag., vol. 46(1), pp. 99-112.

[11] Stoltz, "Bank Capital and Risk-Taking: The Impact of Capital Regulation,” p. 8, 2007.

[12] Surekha, "Bank Capital and Risk-Taking: The Impact of Capital Regulation," Chart. Value, Bus. Cycle. Springer-Verlag, 2001.

[13] Gerson and R. F, Mengukur Kepuasan Pelanggan. Jakarta: PPM, 2002.

[14] I. Ghozali, Aplikasi Analisis Multivariate dengan Program SPSS. semarang: Badan Penerbit Universitas Diponegoro, 2006.

[15] S. Birley, "Marketing Entrepreneur And Bussines Performance," J. SMEs Mark. Entrep., vol. 3, p. 7, 2007.

[16] Kocak, Akin, and Ambibola, "The effect of Entrepreneurial Marketing on Born Global Performance," Int. Mark. Rev., vol. 26, pp. 439-452, 2009.

[17] D. Carson, S. Cromie, M. Gowan, and J. P. and Hill, Marketing And Entrepreneurship in SMEs - An Innovative Approach. London: Prentice Hall, 2008.

[18] Y. Georgelllis, J. P, and A. Woods, "Entrepeneurial Action, Innovation and Enterprise Development," J. SMEs Entrep., vol. 6, p. 2, 2001.

[19] Hadiyati, "Pemasaran Untuk UMKM (Teori dan Aplikasi)," Malang: Bayumedia Publishing, 2010. 